
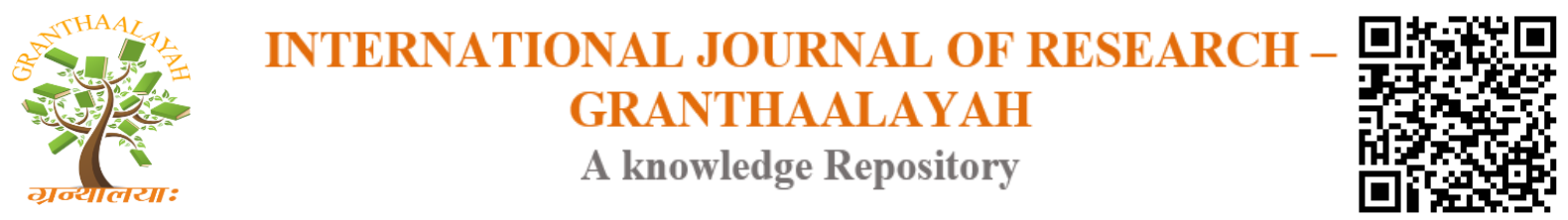

Management

\title{
COLLEGE STUDENT MIND-SET AND INTENTIONS TOWARD ENTREPRENEURSHIP IN CHENNAI CITY
}

\author{
Dr. P. Sankar ${ }^{1}$, A. Irin Sutha ${ }^{2}$ \\ ${ }^{1,2}$ Assistant Professor, Department of Commerce, SRM University, INDIA
}

DOI: https://doi.org/10.29121/granthaalayah.v4.i8(SE).2016.2584

\begin{abstract}
The objective of the present paper is to examine the college student Mind-set and intentions toward entrepreneurship, Entrepreneurship is considered as engine of economic growth. That plays a great role in the economic growth and development of the country, more so in a rapidly developing country like India. Entrepreneurship development today has assumed great significance as it is a key to economic development. Entrepreneurs are the seed of industrial development and its fruits are greater employment opportunities, increase in per capita income, higher standard of living and balanced regional development. The present paper attempts to review and analyze the empirical studies undertaken to find out the entrepreneurial intention among college students and find out the factors influencing their decision to venture in entrepreneurship.
\end{abstract}

Keywords:

Entrepreneurship, Entrepreneurial intention, Students entrepreneurial Mind-set, Venture creation.

Cite This Article: Dr. P. Sankar, and A. Irin Sutha, "COLLEGE STUDENT MIND-SET AND INTENTIONS TOWARD ENTREPRENEURSHIP IN CHENNAI CITY”, International Journal of Research - Granthaalayah, Vol. 4, No. 8: SE (2016): 36-39.

\section{INTRODUCTION}

For generating economic growth and moving towards the entrepreneurial society it is imperative, in the opinion of economic theorists, to have a development of entrepreneurship capital, which reflects a number of different legal, institutional and social factors and forces, and involves also a social acceptance of entrepreneurial behavior, individuals who are willing to deal with the risk of creating new firms and favorable business environment. Hence, entrepreneurial initiative of individuals must be regarded as an important factor of economic growth, whereas a major role in working up attitudes towards life, raising enterprising people is played by educational system, which should be developing and propagating entrepreneurial initiative among students and graduates. Entrepreneurship plays a key role in economic development. Today entrepreneurship is widely recognized both by academics and practitioners as a fundamental factor of economic 
development throughout the world. However, entrepreneurship may influence economic development positively as well as negatively. Therefore, entrepreneurial intention merits scholarly research. And it has been empirically proved to be the best and unbiased predictor of entrepreneurial behavior.

\section{ENTREPRENEURIAL INTENT AMONG STUDENT}

Recently there has been a growing interest in undertaking and intensifying actions promoting and supporting the idea of entrepreneurship as an attractive alternative to wage employment among students. There are several reasons for this interest. Firstly well-educated entrepreneurs are expected to create ventures that grow faster than their counterparts. The importance of education to successful performance of new ventures is well recognized by management parishioners and researchers. Secondly due to the process of restructuring in organisations following intensified competition in the market worldwide, previous advantages with wage employment in large established enterprises, such as job security or reward for loyalty have lost on their actuality, thus increasing the desirability of self-employment.

The unemployment among graduates has also been increasing. Entrepreneurs are the "engines of economic growth". They have brought enormous positive contributions to a country's economic growth and social development. Among the contributions are such as innovation and job creation. As entrepreneurship is synonymous with self-employed, it is believed to be an effective strategy in handling the issue of employability, particularly among the youths. Understanding of the factors that predict entrepreneurial intention is crucial because entrepreneurial behavior is a result of intention. Though entrepreneurial intention has been widely studied by scholars from overseas, the question of their applicability in the local setting still remains. To date, intention of young generation, specifically the millennial generation in our country to embark on entrepreneurship continues to be unclear.

According to Ajzen (1991, pp 181), intention refers to "the indication of how hard people are willing to try, of how much an effort they are planning to exert, in order to perform the behavior". Generally, the stronger the intention, the more likely that a person will perform a particular behavior. It is practical to study intention because actual behavior is difficult to be measured in a research $(\mathrm{Wu}, 2010)$. Entrepreneurial intention is closely related to entrepreneurship behavior. Ajzen (1991) has mentioned that intention is a direct predictor of behavior. Add to this, Krueger et al. (2000) has also explained that entrepreneurial behavior is intentional and a planned behavior. Since entrepreneurial behavior is intentional, many researchers agreed that it can be predicted by entrepreneurial intention (Krueger and Carsrud, 1993)

\section{OBJECTIVES OF THE STUDY}

1) To examine the determinants affecting entrepreneurial intention among college student

2) To assess the level of entrepreneurial intention among college student

3) To verify the relationship between determinants and entrepreneurial intention. 


\section{MAJOR FINDINGS}

- Motivations for entrepreneurship are most strongly correlated with entrepreneur's sociodemographic characteristics especially education, but also household income, entrepreneurs' age and gender.

- The entrepreneur's personal situation at the time of business start-up, and characteristics of the start-up business also show distinct associations with motivations, in particular the cross-over of the entrepreneur's business with his/her previous job, the availability of role models, whether the business was started alone or together with others and the industry sector show

- The evidence in this report points to a general framework which defines a pathway from the demographics and attributes of entrepreneurs, combined with their individual circumstances, which determine a set of motivations which, in a specific context (i.e., what we call a tipping point), trigger the action to take the first steps towards setting up their new business venture.

- A deeper understanding of entrepreneurial motivation - beyond simplistic opportunity and necessity motives - is important, especially when it comes to predicting entrepreneurs' expectations about growing their business and hiring employees, which are closely linked to business success. In contrast, autonomy and family and legacy motivations impact business survival.

\section{CONCLUSION}

This study shows that motivations for starting a business are complex and that motivations other than the traditional opportunity-driven and necessity-driven distinction are more closely related to business survival and success. The analysis of the empirical studies carried out brings out some interesting and encouraging aspects about the entrepreneurial intention of students. It was found that majority of the students $(65 \%)$ were interested in pursuing entrepreneurial careers. The educational background of the students also has an influence on their intention to venture into entrepreneurship. It was found that engineering student were more likely to venture into entrepreneurship than their management and natural science counterparts. One disturbing aspect that was revealed in the studies was that as the level of education increases the likelihood of venturing into entrepreneurship decreasing. The traditional gender influences also emerge as male students are more likely start their business than female students. The age of the students also have an influence on their entrepreneurial intention as it was found that students in the age group 25-30 were more inclined towards entrepreneurship than the middle aged.

\section{REFERENCES}

[1] Bygrave, W.D. (1989) The entrepreneurial paradigm: a philosophical look at its research methodologies, Entrepreneurship Theory and Practice, Fall, pp. 7-26.

[2] Carlson, S. D. (1985). Consistency of attitude components: A new approach for an old problem. Dissertation Abstracts International, 46 (09B), 3261.

[3] Douglas, E., (1999) Entrepreneurship as a career choice. Attitudes entrepreneurial intentions and utility maximizations, Frontiers of Entrepreneurship Research, Babson College, Wellesley, Massachusetts. 
[4] Evan, D, (2005), Individual Intentions towards entrepreneurship Vs Entrepreneurship, working paper, University of Sunshine Coast, Sippy Downs, Australia.

[5] Golden, S. A. R. (2011). A Study On Investment Pattern And Preference Of Investors In Trichy City, Tamil Nadu. RETELL, 12 (1), 20, 24.

[6] Golden, S. A. R. (2011). An Analysis Of Mental Stress In Heavy Alloy Penetrator Project, Tiruchirappalli, SELP Journal of Social Science, Vol- 13, Issue- 1, P- 93 -97.

[7] Golden, S. A. R., \& Regi, S. B. (2015). Satisfaction of Customers towards User Friendly Technological Services offered by Public and Private Sector banks at Palayamkottai, Tirunelveli District. International Journal of Research, 2(3), 775-787.

[8] Rahul, G. S. A. Subscribers' Attitude towards Mobile Communication Service Problems in Tuticorin District. International Journal of Research-Granthaalayah, 4(5), 53-57.

[9] Regi, S. B. S, ARG (2014). “. A DESCRIPTIVE STUDY ON THE ROLE OF CONSUMER PSYCHOLOGY AND BEHAVIOUR IN PRODUCT PURCHASING”. Indian Streams Research Journal, 3.

[10] Regi, S. B., \& Golden, S. A. R. (2014). Customer Preference Towards Innovative Banking Practices Available In State Bank Of India At Palayamkottai. Sankhya International Journal Of Management And Technology, 3 (11 (A)), 31, 33.

[11] Regi, S. B., \& Golden, S. A. R. (2014). Foreign Direct Investment-An Overview. IJARCSMS, 2 (2).

[12] Regi, S. B., \& Golden, S. A. R. (2014). Global Financial Crisis - Impact In India.JOURNAL OF INTERNATIONAL ACADEMIC RESEARCH FOR MULTIDISCIPLINARY, 2(1), JIARM.

[13] Regi, S. B., \& Golden, S. A. R. (2014). Reforms In Insurance Sector In India-A Empirical Study. Review Of Research, 3 (9), 1, 5.

[14] Regi, S. B., \& Golden, S. A. R. (2014). A Study On Educational Loan Availed By Students In Trichy City. Journal Of International Academic Research For Multidisciplinary (Jiarm), 2(1).

[15] Regi, S. B., Golden, S. A. R., \& Franco, C. E. (2014). A DESCRIPTIVE STUDY ON THE PROSPECTS OF E-COMMERCE IN INDIA. Golden Research Thoughts, 3(9), 1-7.

[16] Regi, S. B., Golden, S. A. R., \& Franco, C. E. (2014). ROLE OF COMMERCIAL BANK IN THE GROWTH OF MICRO AND SMALL ENTERPRISES. Golden Research Thoughts, 3(7), 1-5. 